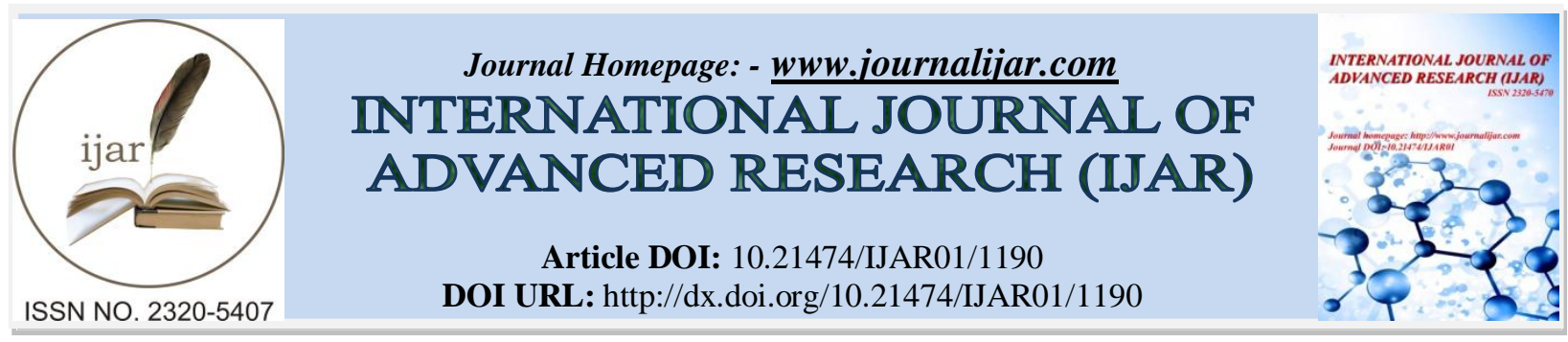

RESEARCH ARTICLE

\title{
PRIMARY NEROENDOCRINE SMALL CELL CARCINOMA OF THE BREAST RARE PATHOLOGY- CASE REPORT.
}

Dr Nabila Javed, Dr Noorul Ain Ainy, Dr Javed Iqbal, Dr Mohammad Rauf Khattak, Dr Rawail A Khan, Dr Zainab Jan, Dr Naheed Akhter, Dr Abbas Ilyas, and Dr Mohammad Iqbal.

\section{Manuscript Info}

Manuscript History

Received: 12 June 2016

Final Accepted: 16 July 2016

Published: August 2016

Key words:-

Neuroendocrine carcinoma Breast.

\begin{abstract}
Small cell neuro-endocrine tumors (NETS) are uncommon and mostly occur in Lung and Gastrointestinal tract while extra pulmonary NETS are rare. Primary small cell carcinoma of the breast is rare entity and less than 40 cases have been reported in the literature worldwide. Diagnosis of primary small cell carcinoma of breast requires histopathological evaluation and positivity of the immunohistochemical stains like synaptophysin and chromogranin and ruling out primary from other sites as well. Standard treatment guide lines have not been yet established because of the rarity of this tumor. Most of the patients reported in the literature have been treated by surgery, chemotherapy, radiotherapy and hormonal therapy for patients whose tumor was estrogen and progesterone receptor positive. We present a case of 60 years old female patient of primary small cell carcinoma of the breast. Investigations were done to rule out any other lesion in the body. She has been staged as IIIB according to TNM staging. She is getting neoadjuvant chemotherapy with significant clinical response.
\end{abstract}

Copy Right, IJAR, 2016,. All rights reserved.

\section{Introduction:-}

Neuroendocrine tumors (NET) of breast are graded as low grade type, NOS (not otherwise specified) and high grade (small cell). According to WHO, NETS in the breast is classified as solid NETS, small cell/oat cell and large cell tumors. Only a small subset of NETS(15-30\%) are functionally active and produce carcinoid syndrome, so most of the cases $(70-85 \%)$ present as an isolated breast mass with or without axillary lymphadenopathy and without any systemic manifestations like cutaneous flushing, migratory erythema, watery diarrhea and palpitations. Typical small cell neuroendocrine carcinoma occurs in lung. Extra pulmonary small cell carcinomas are rare but may occur in variety of organs in order of decreasing frequency such as cervix, esophagus, ovary, pharynx, larynx and prostate. Primary small cell neuroendocrine carcinoma of the breast is infrequent and majority neuroendocrine carcinomas of breast reported in the literature are secondary (90-95\%) and less than 40 cases of primary small cell carcinoma of the breast have been reported up till now in literature internationally and one reported nationally ${ }^{(1)}$. The prognosis, morphology and immunohistochemistry profile of this tumor resembles its pulmonary counterpart ${ }^{(2,3)}$. Diagnosis require ruling out a non-mammary origin. Most patients are in sixth and seventh decade of life and 59\% present with involved lymph nodes. Two cases of primary small cell carcinoma of breast have been published from South East Asia, one from Pakistan and one from India ${ }^{(1,4)}$. 
As it is very uncommon tumor in breast that's why treatment guidelines have not been yet established. Cases reported in the literature have been treated with multimodality approach like surgery, multiagent chemotherapy, radiation and hormonal therapy.

\section{Case Report:-}

A 60 year old postmenopausal patient presented with a history of lump in upper outer quadrant of left breast for two years. It became painful over the last two months. On examination there was a $5 \times 6 \mathrm{~cm} \times 5 \mathrm{~cm}$ hard lump with peau'd orange appearance in upper outer quadrant of left breast with multiple mobile left axillary lymph nodes $(1 \mathrm{x} 1 \mathrm{~cm})$. Mammography revealed speculated lesion $5 \times 4 \times 4 \mathrm{~cm}$ in upper outer quadrant of left breast. Tru-cut biopsy was carried out and histopathological examination showed small cell carcinoma of breast. Immunohistochemical stains were applied, which showed positivity to synaptophysin and chromogranin. CT thorax, abdomen and pelvis were done to exclude extra mamary primary site these were negative for any lesion outside the breast. Bone scan was normal .She was ECOG 1 with normal hematological and biochemical profile. Estrogen, progesterone receptors were positive and HER $2 \mathrm{Neu}$ was negative. She was staged as $\mathrm{T}_{4 \mathrm{~b}} \mathrm{~N}_{1} \mathrm{M}_{0}$; stage IIIB according to TNM staging. She has been started with neoadjuvant chemotherapy inj. Cisplatin 80mg/m2 day1 and inj. Etoposide 100mg/m2 day1-3 with pre medications three weekly. Up till now she has received three cycles of chemotherapy with significant clinical response and tolerating well.

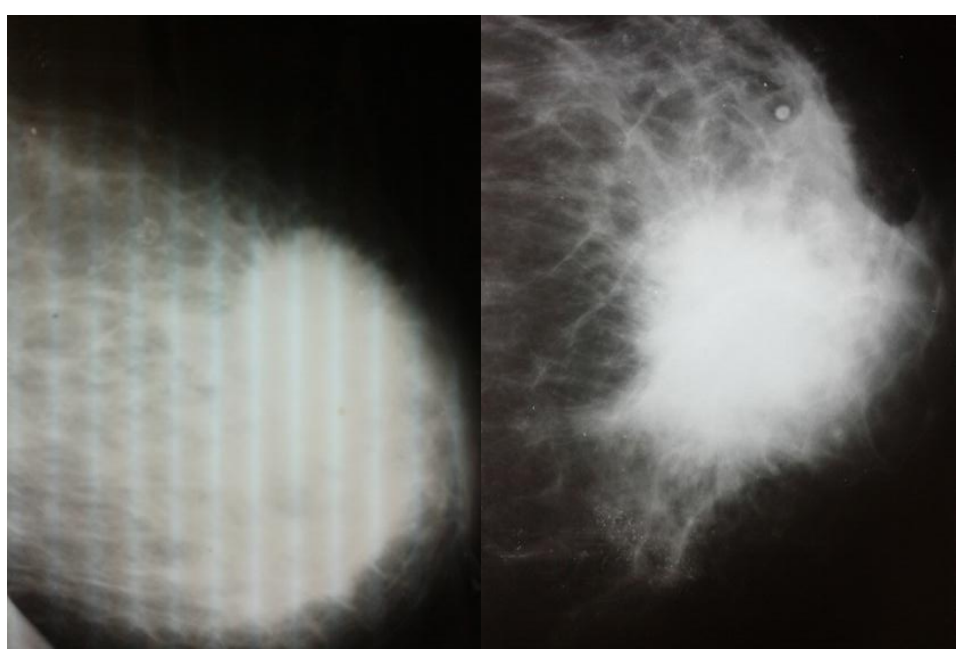

\section{Discussion:-}

Figutre:- Pre Chemotherapy mammogram.

Primary small cell neuroendocrine carcinoma of breast in females is one of the least common pathology and only one case has been reported of male breast worldwide. ${ }^{(5)}$ It may occur at any age but majority of the cases reported were in sixth and seventh decade of life. ${ }^{(6)}$ It is difficult to distinguish metastatic small cell carcinoma from primary small cell carcinoma of breast. It should be distinguished from direct invasion of breast by merkel cell carcinoma, malignant melanoma, lymphoma and metastasis from lung by exact location of tumor and Immunohistochemical stains on histopathology specimen like LCA, S-100 Protein, HMB45, TTF1, neuroendocrine markers like chromogranin and synaphtophysin. Literature reviewed showed 59 cases of NETS in breast in which 38 were primary breast neuroendocrine tumors and 21 were secondary ${ }^{(6)}$ all patients were females except one male patient ${ }^{(5)}$.

Neuroendocrine cells normally are not present in the breast so histiogenesis of small cell carcinoma in the breast remains unclear. it has been suggested that it is the variant of metaplastic carcinoma arising from usual lobular or ductal carcinoma ${ }^{(7)}$.Some studies suggest that presence of an in situ carcinoma component within the breast was highly suggestive of a breast primary rather than a metastatic tumor ${ }^{(8)}$ First documented case of primary small cell carcinoma of the breast reported by Wade et al claimed that both the presence of extensive regional metastasis and radiographic studies that excluded other tumors in theses patients supported a primary breast lesion ${ }^{(9)}$

Our case represent a classical example of primary small cell carcinoma of breast, since patient showed axillary lymph node metastasis in absence of pulmonary or any other primary origin.Her age was 60 years which also corresponds to the age mentioned in literature review(7). 
Most of the patients have been treated with multidisciplinary approach including surgery, adjuvant chemotherapy and radiotherapy followed by hormonal therapy in estrogen and progesterone receptor positive patients ${ }^{(10)}$. Shin et al, conducted a study in which eight out of nine patients underwent mastectomy with axillary dissection. Seven patients received adjuvant chemotherapy and four received radiation, two patients received tamoxifen. All patients were alive at last follow up 3-35 months after treatment.66\% of patients were estrogen progesterone receptor positive and negative for $\mathrm{Her} 2-\mathrm{Neu}^{(7)}$.

Prognosis of primary small cell carcinoma of the breast is debatable because of lack of long term survival data among these patients. The stage of the disease at the time of diagnosis is a determinant factor in its evolution

${ }^{(7)}$.Estrogen and progesterone receptors are important markers for directing therapy and determination of prognosis. New case series containing large number of patients are needed to even out the standard treatment protocols for this rare tumor.

\section{References:-}

1. Ayesha saeed,Abdul rehman,Syed Amjad H Zaidi,Tauseef Shaukat,et al.Neuroendocrine carcinoma of breast:JCPSP2011;21(6):371-373.

2. Yamasaki T,ShimazakiH,Aida S et al.Primary small cell (oat cell carcinoma of the breast:Report of a case and review of the literature.Patholint 2000;50:914-18.

3. Samli B,Celik s,Evrensel T,et al.Primary neuroendocrine small cell carcinoma of the breast.Arch Pathol Lab Med 2000;124:296-8.

4. Akhtar K,Zaheer S,Ahmad SS,Hassan MJ.Primary neuroendocrine carcinoma of the breast.Indian J pathol microbiol 2009;52:71-3

5. Jundt G,Schulz a,Heitz PU et al.Small cell neuroendocrine(oat cell)carcinoma of the male breast.Immunocytochemical and ultrastructural investigations.Virchows arch A Pathol Anat Histopathol $184 ; 404: 213-21$

6. Upalakalin JN,Collins LC,Tawa N,Parangi S.Carcinoid tumours in the breast.Am J Surg 2006;191:799-805.

7. Shin SJ,Delellis RA,Ying L,Rosen PP.Small cell carcinoma of the breast:a clinicopathologic and immunohistochemical study of nine patients.Am J Surg Pathol 2000 ;24(9):1231-87.

8. Papotti M,Gherardi g,Eusebi V,Pagani A,Bussolati G.Primary oat cell (neuroendocrine) carcinoma of the breast.Virchows Arch A pathol Anat Histopathol.1991;420:103-108.

9. Wade PM,Mills SE,Read M,Cloud W,Lambert MJ,Smith RE.Small cell neuroendocrine (oat cell) carcinoma of the breast.Cancer.1983;52:121-125.

10. Billur samli,MD,Selma Celik MD,Turkkan Evrensel MD,Bulent Orhan MD,Ismet Tasdelen MD.Primary Neuroendocrine small cell carcinoma of the Breast.Arch Pathol Lab med2000;124:296-298. 